\title{
Aggregate Public-Private Remuneration Patterns in South Africa
}

\author{
Andreas Wörgötter ${ }^{1}$ (D) $\cdot$ Sihle Nomdebevana ${ }^{2}$
}

Published online: 3 December 2020

(C) The Author(s) 2020

\begin{abstract}
This paper investigates the public-private remuneration patterns in South Africa with time-series methods for the first time since the introduction of an inflationtargeting framework in 2000. Co-integration tests and analysis confirm that there is a stable, long-run relationship between nominal and real remuneration in the public and private sector. The adjustment to the deviations from this long-run relationship is strong and significant for public-sector remuneration, while private-sector wages neither respond to deviations from the long-run relationship nor lagged changes in publicsector remuneration. The causal direction from private- to public-sector remuneration does not change if real earnings are calculated with the gross domestic product deflator. This is confirmed by simple Granger-causality tests.
\end{abstract}

Keywords South Africa $\cdot$ Remuneration pattern $\cdot$ Public sector earnings $\cdot$ Private sector earnings $\cdot$ Co-integration $\cdot$ Granger causality $\cdot$ Dutch disease

JEL $\mathrm{C} 32 \cdot \mathrm{E} 64 \cdot \mathrm{J} 31$

\section{Introduction}

This paper provides an empirical investigation into the nature of remuneration pattern outcomes in South Africa by examining the relationship between public- and privatesector wages. It complements studies that are concerned with structural differences

Andreas Wörgötter

Andreas.Woergoetter@econ.tuwien.ac.at

1 Institute of Statistics and Mathematical Methods in Economics, University of Technology, Vienna, Austria

2 South African Reserve Bank, Pretoria, South Africa 
between public- and private-sector employment and remuneration (Bosch 2006; Mavromaras et al., 2017). The empirical and theoretical literatures suggest a relationship between public- and private-sector wages. The direction of causality is tested using Granger-causality analysis and applying vector-error-correction models (VECMs) with quarterly data from South Africa for the period 2000 to 2016.

Remuneration patterns constitute an important linkage between the micro- and macro-spheres of the economy. On the microlevel, they reflect the incentives and constraints for individual decisions about how many hours to work and which wage to accept. On the macrolevel, wage dynamics have important consequences for inflation, unemployment and, through work experience, productivity. Together, this affects the sacrifice ratio or, in other terms, the real costs needed to maintain price stability. For instance, in a bargaining system with more than one trade union, wage leadership reduces the effective number of independent trade unions and increases the degree of centralisation of wage bargaining. Assuming that the leading trade union has some degree of inflation aversion, this could allow the central bank to be more accommodative while simultaneously reducing inflation and unemployment to their lowest socially optimal levels (Coricelli et al., 2006). Without referring to monetary policy regimes, either completely centralised or completely decentralised, bargaining systems are associated with better macroeconomic performance (Calmfors and Driffill, 1988).

One of the reasons why the remuneration pattern is important comes from the structural diversity of the economy. A familiar approach is to distinguish between economic activity that is exposed to international competition, and economic activity that is not as exposed. The separation into a public sector and a private sector, which is applied in this paper, makes the same distinction. Exporters, especially when located in small, open economies, usually face competition from other global suppliers. Maintaining cost and price competitiveness imposes an immediate constraint on wage-cost dynamics. This does not mean that the wages paid by export-oriented producers should be lower. It only means that external competition guides how far wage costs can go. Suppliers serving the domestic economy face competition only from among themselves and potential market entrants. The strength of the competition then depends on technological characteristics, market size and regulation. Usually, domestic competition, when sheltered from international suppliers, is less fierce than in export-oriented sectors, and the scope for open or tacit collusion is potentially significant.

The public sector is free from competition concerns on the supply side. The wage bill is constrained by the budget, while the earnings and employment split are influenced by alternative options in the private sector (Fearon 2004). Furthermore, there is evidence for a close relationship between the wage rate and per capita government spending in South Africa (Alm and Embaye, 2010). This could also be linked to the stated policy goals in the National Development Plan (NDP) and the New Growth Path (NGP), as well as earlier strategic policy documents, which put poverty alleviation at the centre of government policies (NDP 2012; NGP 2011). In general terms, one can assume that private-sector earnings are driven more by market developments than by public-sector earnings. Therefore, the direction of causality either increases (for public-sector earnings following the private-sector developments) or decreases (for private-sector following public-sector earnings) the role of market forces. 
Therefore, different exposure to competition in the product markets generates a different framework for wage negotiations and outcomes, even if labour-force regulation (specifically dismissal protection) is applied uniformly throughout the economy. This heterogeneity becomes even more important if wage bargaining follows a pattern, meaning that negotiations in one sector follow the outcomes in another sector. In such cases, the orientation of the wage leader to price stability has important consequences for the sacrifice ratio, which is determined by the pressure on the wage-formation process to limit inflationary wage increases.

Perhaps this is most true for the relationship between public- and private-sector earnings because there is an asymmetry of budget constraints between the two sectors. In other words, the public sector has the capacity to let the earnings of its employees deviate from the private sector, regardless of market forces. Therefore, the public- and private-sector earnings pattern is relevant for the efficiency of market forces contributing to the restoration and subsequent maintenance of a labour-market equilibrium.

\section{Literature Review}

The theoretical literature on pattern bargaining takes two opposing views. One string of literature, strongly influenced by Calmfors and Driffill (1988), takes an institutional approach linking bargaining outcomes to the setup of the bargaining framework. In this context, not all externalities may be considered by individual economic agents. For instance, excessive payroll taxation and regulatory interference into wage formation can contribute to a loss of external competitiveness and a growing gap between productivity and wage costs (Agudelo and Sala, 2016). Beyond competitiveness, there is also the issue of fairness and excessive inequality of pay (Gwatidzo and Benhur, 2013), which is particularly important for economies where monopsony plays a role.

Following this literature, pattern bargaining possibly has a positive role to play for removing information asymmetries and internalising externalities, for instance, from wage growth on inflation. This literature treats labour organisations, like trade unions, as exogenous.

Alternatively, authors like Pollan (2004) considered the institutional setup, including coverage of collective bargaining, as part of an economic optimisation process. In this respect, pattern wage bargaining cannot improve outcomes compared with decentralised bargaining under inflation targeting (Calmfors and Seim, 2013). This is less relevant for the public- and private-sector earnings pattern because the public- and private-sector split can be considered exogenous and only slowly changing.

However, when the public- and private-sector supply of services is endogenous, for instance, because of a credible threat of outsourcing, wage demands in the public sector follow agreements in the private sector (Fearon 2004). If the private sector is booming, wages in the public sector also rise. If private-sector firms are successfully bidding for outsourcing contracts, then public-sector unions make concessions.

In the area of macrostructural interactions, the Scandinavian model of inflation links inflation differentials to sectoral productivity differences in a model with centralised and solidaric wage determination (Frisch 1977). In this model, the higher structural rate of inflation, which comes from lower productivity growth in 
the domestic sector, does not pose a problem for international competitiveness. The wage leader in the export sector sets wage increases on a level compatible with international competitiveness. This pattern of wage outcomes is in line with macroeconomic stability and contributes to a lower sacrifice ratio. The disciplining effect of unemployment on wage formation is replaced by internalisation of the concern for international competitiveness through a centralised bargaining process with monopoly trade unions and employer associations. An important assumption in this model is that the size of the two sectors is exogenously given. In this type of model, private-sector earnings lead public-sector earnings because the wage ceiling is established by maintaining international competitiveness.

Dutch disease models describe cases in which one sector (usually resource extraction) grows because of newly discovered profitable deposits (like the gas fields in the Netherlands) and a wage differential becomes necessary to attract workers from other sectors, mainly manufacturing. It is assumed that labour is not internationally mobile. The disease element of this otherwise beneficial setting comes from the spillover of wage increases to sectors that face international competition (and therefore cannot pass on wages to higher prices), or sectors that face technological and organisational barriers to increasing productivity. As a consequence, more workers lose jobs in export-oriented manufacturing than can find new employment opportunities either in mining or in the services sectors, which benefit from the higher incomes generated by mining sector expansion. A variant of the Dutch disease can arise if internationally determined rawmaterial prices increase and, thus, increase the profitability of mining exports (Ahrend et al., 2007).

For South Africa, mining is an important contributor to economic activity, exports and jobs. While in the past productivity advances allowed mines to operate longer, internationally determined raw-material prices became the dominant determinant of the profitability of the sector from the beginning of the 2000s (Gwatidzo and Benhur, 2013). A similar context, as in the case of Dutch disease, may distort the wage-setting process in post-communist countries (D'Adamo 2014). In these countries, the government played a large role in the redistribution of income and wealth through privatisation and the restructuring of state-owned enterprises. Therefore, it is not surprising to find many cases of wage leadership by the public sector. This could also be the case for South Africa if government revenue from mining is spent to increase public-sector wages above private-sector wages (including in the export industries).

In all variants of the Dutch disease, wage pressures arise that are not in line with macroeconomic stability and contribute to an increase in the sacrifice ratio. This is also the case if the government benefits from extra revenue used to increase wages in the public sector.

In most member countries of the Organisation for Economic Cooperation and Development (OECD), public-sector wages follow the outcomes of private-sector wage negotiations (Lamo et al., 2012). However, there are also cases of public-sector leadership and spillover effects (Afonso and Gomes, 2014).

For Sweden, the private sector is the wage leader and the public sector follows (Lindquist and Vilhelmsson, 2006). Public-sector wages do not Granger cause privatesector wages. For Austria, using data on collectively bargained wages, reference norms play a significant role. External norms seem to matter more than internal norms (Knell 
and Stiglbauer, 2012). However, in an earlier paper, Pollan (2004) found that Austrian remuneration outcomes characterised by high and rising diversity were incompatible with a wage-pattern hypothesis. For the United States, Marshall and Merlo (2004) found that trade unions preferred pattern bargaining over simultaneous industry-wide bargaining and sequential bargaining with a random pattern. They also pointed out that pattern bargaining promoted significant entry barriers. This could also be the case for South Africa if public-sector wages cause private-sector wages to follow and new market entrants cannot afford to hire labour.

For the euro area, Germany acts as a wage leader (Ramskogler 2012). This could have encouraged the European Central Bank to run accommodative monetary policy despite the warning signals from an overheating housing market during the run-up to the most recent global financial crisis.

\section{Wage Formation}

South Africa has a decentralised trade union structure. Unionisation is high in the public sector and mining. It is intermediate in manufacturing and transport, and low in trade, finance and construction. Additionally, unionisation is close to zero among personal services employees (Wittenberg and Kerr, 2019). Wage negotiation is centralised in the public sector through a bargaining council. Collective agreements for the private sector are concluded by sectoral and regional bargaining councils, which are extended to non-members by ministerial decree if the concluding social partners are sufficiently representative. Cost of living adjustments are part of wage negotiations for the first year in the contract, but automatic indexation to forecasted changes in the Consumer Price Index (CPI) are usual for the second year. Collective agreements usually span two years. A theoretical foundation for the relationship between publicand private-sector remuneration was derived by modelling a sequential game between a government ministry, the public service provider, a public-sector union and a private service provider (Fearon 2004).

\section{Data}

Quarterly average remuneration (earnings) data were used from the first quarter of 2000 to the first quarter of 2017 for both the public and private sectors. The choice of the observation period was motivated by the introduction of South Africa's inflationtargeting regime. Real remuneration is calculated by deflation with the deflator of gross value added excluding agriculture, following the methodology applied by Statistics South Africa (Stats SA 2020).

Remuneration data were collected by Stats SA (2020). Seasonal adjustment was carried out by the South African Reserve Bank (SARB 2018). The term earnings is used synonymously with remuneration.

Figure 1 shows the development of both public- and private-sector remuneration, together with the CPI. The CPI is shown because it is the headline inflation measure most popular in South Africa. All the variables are presented in logarithmic terms. 


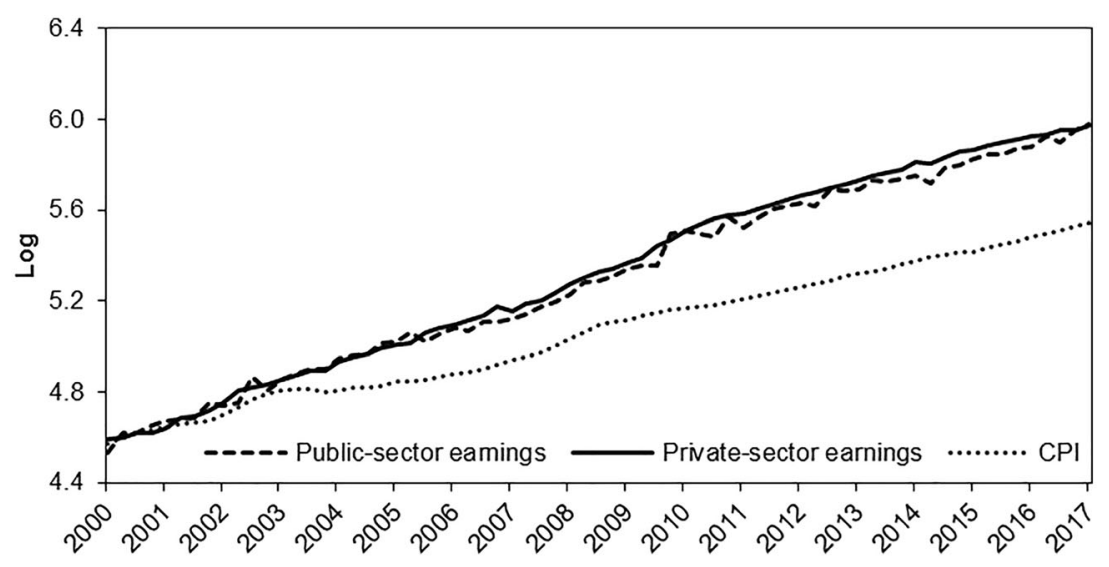

Fig. 1 Nominal public- and private-sector earnings and the consumer price index (log). Source: Own calculations using data from SARB (2018) and Stats SA (2020)

Visual inspection of the data signals that private-sector earnings progress relatively smoothly, with only some cyclical responses, while public-sector remuneration is much more volatile. The CPI is quite smooth but shows more pronounced cycles.

These observations are confirmed by the descriptive statistics in Table 1 . The nominal public- and private-sector earnings grow, on average, by $2.0 \%$ per quarter (by $8.1 \%$ and $8.2 \%$, respectively, when annualised). Consumer price inflation amounts to $1.4 \%$ per quarter, which is equivalent to average annual inflation of $5.6 \%$.

While the rate of earnings increases in the public and private sectors is nearly identical, development in the public sector is much more volatile than in the private sector. The standard deviation of public-sector remuneration is about 2.5 times as large as in the private sector. This feature is preserved for the deflated earnings. In other words, consumer price inflation does not contribute to earnings volatility. Therefore, the higher volatility of public-sector earnings must be explained by other factors. It is worthwhile noting that the ratio between average nominal and average real earnings growth is above 5, which is unusually high, even for an emerging economy.

Figure 2 shows the development of real remuneration. It suggests that public-sector remuneration is much more volatile than private-sector remuneration.

Figure 3 shows the smoothed year-on-year growth rates of nominal and real publicand private-sector earnings. For both the nominal and the real series, public-sector earnings growth fluctuates around private-sector earnings, suggesting a pattern characterised by private-sector earnings being the mean by which public-sector

Table 1 Descriptive statistics for changes in logs of nominal public (D(LWPU)) and private (D(LWPR)) and real public (D(LRWPU)) and real private (D(LRWPR)) earnings and the Consumer Price Index (D(LCPI))

\begin{tabular}{llllll}
\hline & $\mathrm{D}($ LCPI $)$ & $\mathrm{D}($ LWPU $)$ & $\mathrm{D}($ LWPR $)$ & $\mathrm{D}$ (LRWPU) & $\mathrm{D}($ LRWPR $)$ \\
\hline Mean & 0.014 & 0.020 & 0.020 & 0.003 & 0.004 \\
Standard deviation & 0.008 & 0.033 & 0.013 & 0.032 & 0.014 \\
\hline
\end{tabular}

Note: Since real earnings are deflated with a different price index, the adding-up conditions are not met. Source: Own calculations using data from SARB (2018) and Stats SA (2020). 


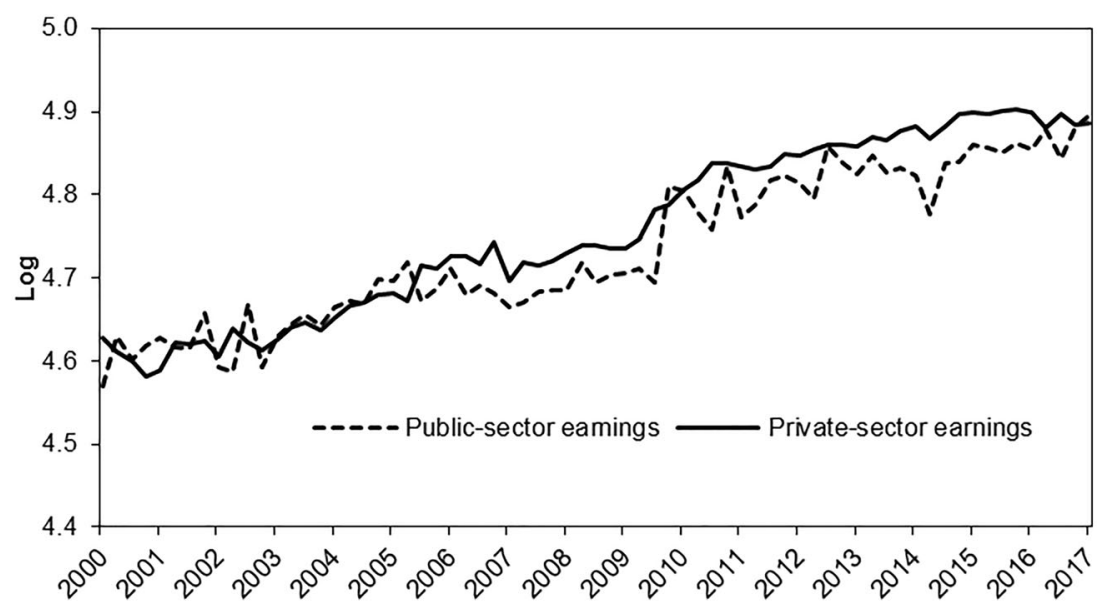

Fig. 2 Real public- and private-sector earnings. Source: Own calculations using data from SARB (2018) and Stats SA (2020)

earnings revert. It is interesting to note that public-sector wages fell behind in the boom years before the global financial crisis and caught up during the crisis years, 20092010. In contrast, this happened to other countries where public-sector wage growth was constrained as part of a fiscal consolidation strategy (Biesenbeek and Werff, 2019). According to this pattern, public-sector earnings should moderate again in the near future and cross the private-sector earnings growth line from above.

\section{Estimates}

The short- and the long-run public- and private-sector earnings patterns were tested using the well-known Granger-causality test and the VECM methodology (Johansen 1991). Lamo et al. (2012) applied the same methodology for their investigation of public- and private-wage patterns in OECD countries. Granger causality follows a simple post-hoc-
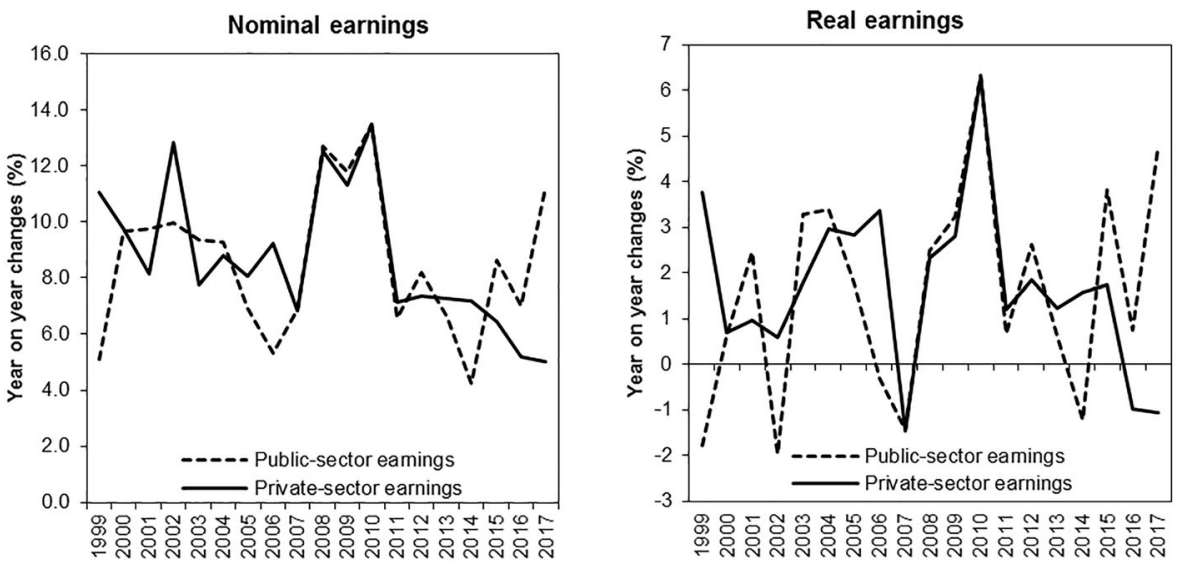

Fig. 3 Nominal and real public- and private-sector earnings changes. Source: Own calculations using data from SARB (2018) and Stats SA (2020) 
ergo-propter-hoc approach. In other words, it is assumed if an impact follows a shock in time, one can conclude that the cause of the impact is the shock. If a co-integrating relationship is found, there must be Granger causality in one direction or the other. The direction of causality was determined by the VECM (Odhiambo 2009). The approach was heavily criticised as atheoretic (Cooley and Leroy, 1985), but became an established empirical tool.

Table 2 shows the results of a simple Granger-causality test between the quarter-onquarter changes of logged public- and private-sector earnings. The null hypothesis of no causality was rejected for nominal and real private-sector earnings causing publicsector earnings at a 5\% significance level. The null hypothesis cannot be rejected for public-sector earnings causing private-sector earnings.

The simple Granger test only takes the information from the first differences into account. Therefore the Granger test catches only the short-run elements of earnings leadership. VECMs also use information about levels and cover the long-run aspects of earnings leadership. The VECM methodology (Juselius 2006) combines the estimate of a long-run relationship among the endogenous variables (in this case, public- and private-sector earnings) with the short-run adjustment towards it.

Table 3 reports the bi-variate co-integration tests for nominal remuneration in the public and private sectors and the CPI, as well as for real remuneration in the public and private sectors. The results reject the null hypothesis of no co-integration relationship between nominal and real remuneration in the public and private sectors, respectively. On the contrary, co-integration between nominal remuneration in the public and private sectors, respectively, and the CPI cannot be rejected.

VECM and vector autoregression (VAR) estimates were calculated for nominal and real public- and private-sector remuneration. Table 4 summarises the results of these estimates. Complete information is provided in the Online Supplemental Appendix.

No co-integration was rejected for nominal public- and private-sector earnings. Contrary to Lamo et al. (2012), the unit coefficient for the co-integrating relationship was estimated rather than imposed. It turns out that the estimated coefficient of privatesector earnings was close to, but significantly below 1 ( -0.958 for nominal earnings and -0.843 for real earnings).

Table 2 Granger-causality test for the public- and private-sector earnings patterns

\begin{tabular}{|c|c|c|c|}
\hline Null hypothesis & Observations & F-statistic & $p$-value \\
\hline \multicolumn{4}{|l|}{ Nominal earnings } \\
\hline $\begin{array}{l}\text { Nominal private-sector earnings do not Granger } \\
\text { cause public-sector earnings }\end{array}$ & 66 & 3.926 & 0.024 \\
\hline $\begin{array}{l}\text { Nominal public-sector earnings do not Granger } \\
\text { cause private-sector earnings }\end{array}$ & & 0.156 & 0.855 \\
\hline \multicolumn{4}{|l|}{ Real earnings } \\
\hline $\begin{array}{l}\text { Real private-sector earnings do not Granger } \\
\text { cause public-sector earnings }\end{array}$ & 66 & 3.370 & 0.040 \\
\hline $\begin{array}{l}\text { Real public-sector earnings do not Granger cause } \\
\text { private-sector earnings }\end{array}$ & & 0.260 & 0.771 \\
\hline
\end{tabular}

Source: Own calculations using data from SARB (2018) and Stats SA (2020). 
Table 3 Co-integrating relationships for nominal and real remuneration in the public and private sectors and the Consumer Price Index

\section{D(LWPU) D(LWPR) D(CPI)}

Co-integrating relationship $\quad \mathrm{LWPU}=(0.963 * \mathrm{LWPR})+0.169$ (no co-integration is rejected)

LWPU and LCPI: no co-integration is not rejected

LWPR and LCPI: no co-integration is not rejected

Descriptive statistics for changes in logs of real earnings

\section{D(LRWPU) D(LRWPR)}

Co-integrating relationship

LRWPU $=(0.840 *$ LRWPR $)+0.737$ (no co-integration is rejected)

Source: Own calculations using data from SARB (2018) and Stats SA (2020).

Nominal public-sector remuneration follows nominal private-sector remuneration because the estimated coefficient of the error-correction term (the lagged deviation

Table 4 VECM estimates (2000Q3:2017Q1) of co-integration between public- and private-sector earnings

\begin{tabular}{|c|c|c|c|c|c|}
\hline \multicolumn{3}{|c|}{ Nominal earnings: D(LWPU) D(LWPR) } & \multicolumn{3}{|c|}{ Real earnings: D(RLWPU) D(RLWPR) } \\
\hline \multicolumn{3}{|c|}{ Co-integrating (long-run) relationship } & \multicolumn{3}{|c|}{ Co-integrating (long-run) relationship } \\
\hline LWPU(-1) & 1.000 & & LRWPU(-1) & 1.000 & \\
\hline $\operatorname{LWPR}(-1)$ & -0.958 & & LRWPR(-1) & -0.843 & \\
\hline \multirow[t]{2}{*}{ Standard error } & $(0.009)$ & & & $(0.038)$ & \\
\hline & {$[-104.315]$} & & & {$[-21.954]$} & \\
\hline $\mathrm{C}$ & -0.199 & & $\mathrm{C}$ & -0.720 & \\
\hline Error correction & D(LWPU) & D(LWPR) & Error correction & D(RLWPU) & D(RLWPR) \\
\hline \multirow[t]{3}{*}{ CointEq1 } & -0.791 & 0.045 & CointEq1 & -0.710 & 0.118 \\
\hline & $(0.175)$ & $(0.091)$ & & $(0.173)$ & $(0.095)$ \\
\hline & {$[-4.502]$} & {$[0.495]$} & & {$[-4.092]$} & {$[1.212]$} \\
\hline \multirow[t]{3}{*}{ D(LWPU(-1)) } & -0.108 & 0.002 & D(LRWPU(-1)) & -0.113 & -0.053 \\
\hline & $(0.122)$ & $(0.063)$ & & $(0.125)$ & $(0.069)$ \\
\hline & {$[-0.885]$} & {$[0.032]$} & & {$[-0.901]$} & {$[-0.778]$} \\
\hline \multirow[t]{3}{*}{ D(LWPR(-1)) } & -0.046 & -0.105 & D(LRWPR(-1)) & 0.166 & -0.220 \\
\hline & $(0.263)$ & $(0.137)$ & & $(0.229)$ & $(0.126)$ \\
\hline & {$[-0.177]$} & {$[-0.768]$} & & {$[0.723]$} & {$[-1.747]$} \\
\hline \multirow[t]{3}{*}{$\mathrm{C}$} & 0.023 & 0.022 & $\mathrm{C}$ & 0.003 & 0.005 \\
\hline & $(0.006)$ & $(0.003)$ & & $(0.003)$ & $(0.001)$ \\
\hline & {$[3.863]$} & [7.104] & & [1.189] & [2.908] \\
\hline R-squared & 0.449 & 0.025 & R-squared & 0.426 & 0.099 \\
\hline Adj. R-squared & 0.423 & -0.020 & Adj. R-squared & 0.398 & 0.056 \\
\hline F-statistic & 17.146 & 0.554 & F-statistic & 15.601 & 2.322 \\
\hline Mean dependent & 0.020 & 0.020 & Mean dependent & 0.003 & 0.004 \\
\hline SD dependent & 0.033 & 0.013 & SD dependent & 0.032 & 0.014 \\
\hline
\end{tabular}

Note: Bolded coefficients are significant at the 5\% level. Source: Own calculations using data from SARB (2018) and Stats SA (2020). 
from the co-integrating relationship) is negative $(-0.791)$ and significant (standard deviation $=0.175$ ) in the equation for public-sector earnings changes. The error-correction term enters the equation for private-sector earnings changes with only a small $(0.002089)$ and insignificant (standard deviation $=0.091)$ coefficient.

The explanatory power is high for public-sector remuneration $\left(\mathrm{R}^{2}=0.449\right.$ for nominal earnings and 0.426 for real earnings) and insignificant for private-sector remuneration ( 0.025 for nominal earnings and 0.099 for real earnings). In other words, information on the past changes in private-sector earnings, as well as deviations from the co-integrating relationship, explains about $40 \%$ of the variance of public-sector earnings growth. Previous changes in public-sector earnings and deviations from the co-integrating relationship have no explanatory power for nominal or real private-sector earnings.

The adjustment is strong and rapid. About $80 \%$ of the deviation from the cointegrating relationship is compensated for by public-sector earnings changes within one quarter. The reaction of private-sector earnings to deviations from the cointegrating relationship is small and insignificant. Figures 4 and 5 show the response of public- and private-sector earnings to a $1 \%$ shock in private- and public-sector earnings. Slightly more than $80 \%$ of private-sector earnings shock remains permanent in private- and public-sector earnings after four quarters, while only $5 \%$ of a publicsector earnings shock remains permanent. The coefficients of past changes of publicand private-sector earnings in the VECM (Table 4) are small and insignificant.

The estimation results of a VAR model with two lags (Table 5) confirm this paper's main finding of a causal relationship from private-sector earnings on public-sector earnings with only insignificant feedback. In line with the Granger-causality test

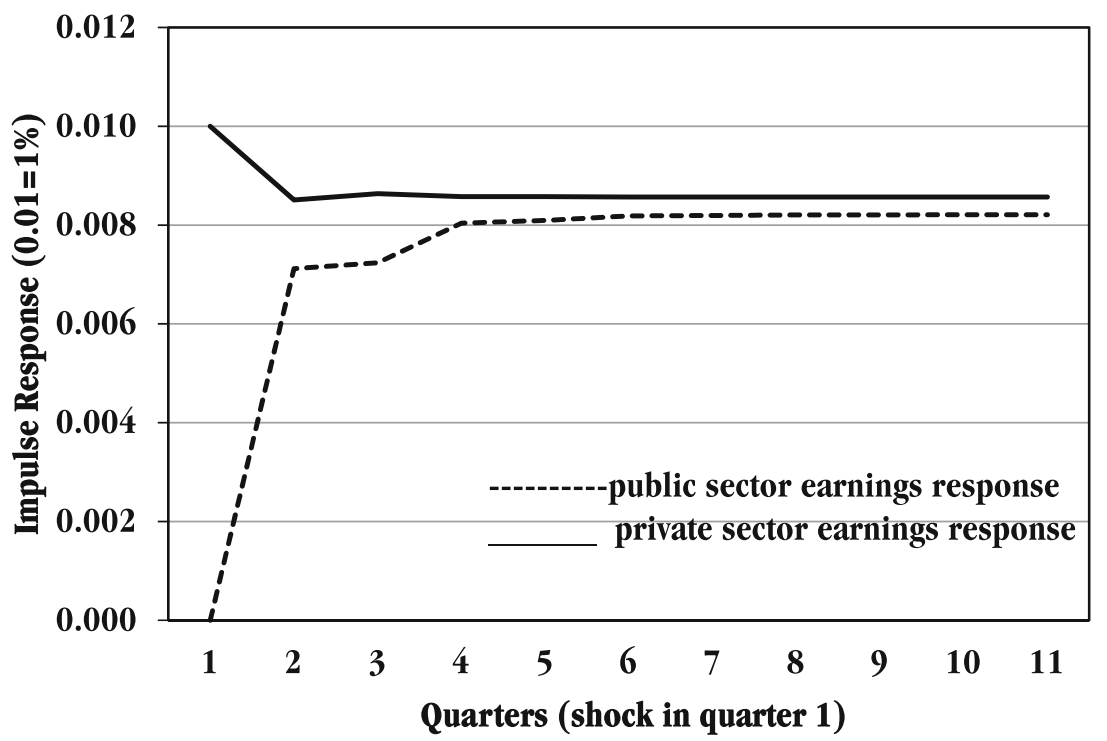

Fig. 4 Response to a $1 \%$ private sector earnings shock. Source: Own calculations using data from SARB (2018) and Stats SA (2020) 


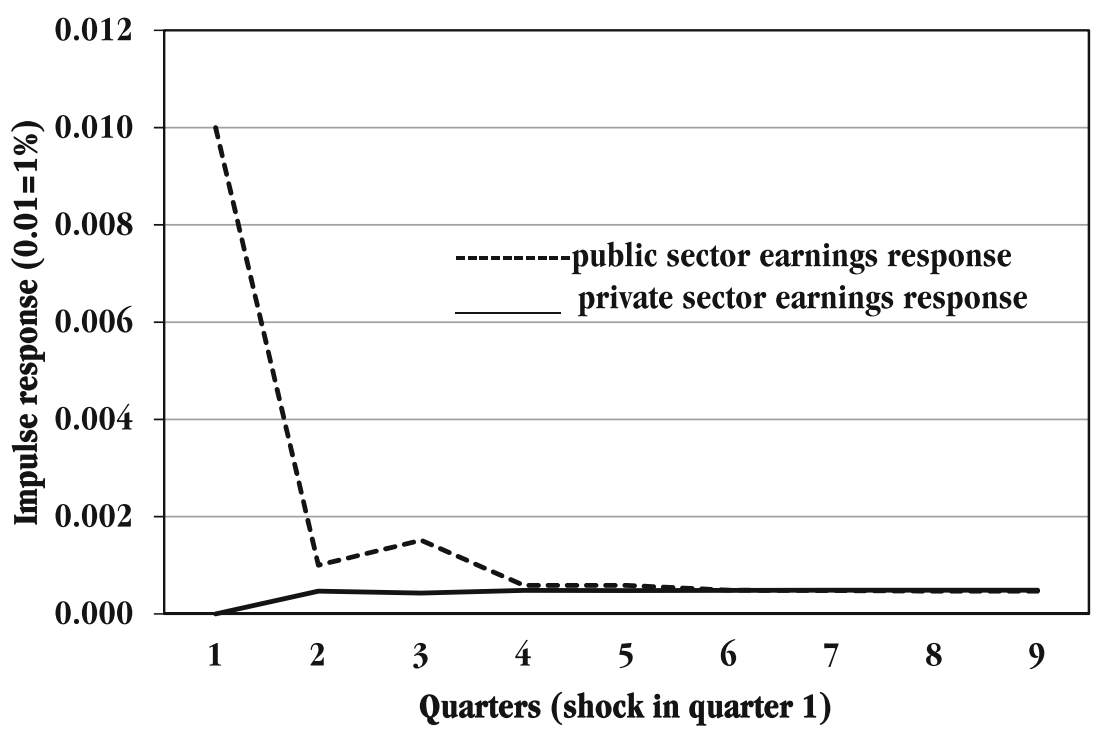

Fig. 5 Response to a $1 \%$ public sector earnings shock. Source: Own calculations using data from SARB (2018) and Stats SA (2020)

(Table 2), only lagged changes in private-sector earnings are significant in the publicsector earnings equation, but lagged changes in public-sector earnings are insignificant in the private-sector earnings equation.

\section{Conclusions}

Two hypotheses of patterns in remuneration outcomes were explored in this paper. First, is there a relationship between nominal remuneration in the public and private sectors? Second, is there a relationship between real remuneration in the public and private sectors?

The Granger-causality test and VECM estimates strongly suggest that publicsector remuneration follows private-sector remuneration in the short- and long-run without feedback. This pattern also holds for real remuneration in the public and private sectors.

Past observations of public-sector remuneration had no explanatory power for private-sector remuneration. A large difference in explanatory power was also confirmed for the deflated remuneration series. The similarity of the estimation results with nominal and real remuneration data suggests that the response to inflation shocks is similar for public- and private-sector remuneration, although there is more stability in the relationship between inflation and public-sector earnings compared with privatesector earnings.

The main conclusion for economic policy is that efforts to reduce excessive nominal wage growth concerning the credible inflation target ${ }^{1}$ should not exclude the private

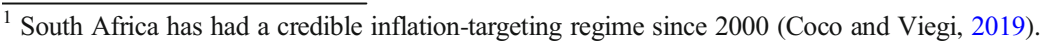


Table 5 VAR estimates (2000Q4:2017Q1) of Granger causality between public- and private-sector earnings

\begin{tabular}{|c|c|c|c|c|c|}
\hline & \multicolumn{2}{|c|}{$\begin{array}{l}\text { Nominal earnings: } \\
\text { DLWPU DLWPR }\end{array}$} & & \multicolumn{2}{|c|}{$\begin{array}{l}\text { Real earnings: } \\
\text { DLRWPU DLRWPR }\end{array}$} \\
\hline & DLWPU & DLWPR & & DLRWPU & DLRWPR \\
\hline \multirow[t]{3}{*}{ D(LWPU(-1)) } & -0.718 & 0.032 & D(LRWPU(-1)) & -0.702 & -0.001 \\
\hline & $(0.117)$ & $(0.058)$ & & $(0.115)$ & $(0.063)$ \\
\hline & {$[-6.099]$} & {$[0.547]$} & & {$[-6.104]$} & {$[-0.024]$} \\
\hline \multirow[t]{3}{*}{ D(LWPU(-2)) } & -0.384 & 0.010 & D(LRWPU(-2)) & -0.449 & -0.038 \\
\hline & $(0.113)$ & $(0.056)$ & & $(0.109)$ & $(0.060)$ \\
\hline & {$[-3.388]$} & {$[0.183]$} & & {$[-4.092]$} & {$[-0.638]$} \\
\hline \multirow[t]{3}{*}{$\mathrm{D}(\operatorname{LWPR}(-1))$} & 0.621 & -0.135 & D(LRWPR(-1)) & 0.595 & -0.302 \\
\hline & $(0.257)$ & $(0.128)$ & & $(0.230)$ & $(0.126)$ \\
\hline & {$[2.412]$} & {$[-1.060]$} & & {$[2.585]$} & {$[-2.397]$} \\
\hline \multirow[t]{3}{*}{ D(LWPR(-2)) } & 0.479 & 0.056 & $\mathrm{D}(\operatorname{LRWPR}(-2))$ & 0.239 & 0.006 \\
\hline & $(0.266)$ & $(0.132)$ & & $(0.239)$ & $(0.130)$ \\
\hline & {$[1.803]$} & {$[0.430]$} & & {$[1.000]$} & {$[0.047]$} \\
\hline \multirow[t]{3}{*}{$\mathrm{C}$} & 0.020 & 0.021 & $\mathrm{C}$ & 0.005 & 0.005 \\
\hline & $(0.008)$ & $(0.004)$ & & $(0.003)$ & $(0.001)$ \\
\hline & {$[2.293]$} & {$[4.785]$} & & {$[1.567]$} & {$[2.944]$} \\
\hline R-squared & 0.398 & 0.029 & R-squared & 0.423 & 0.102 \\
\hline Adj. R-squared & 0.359 & -0.033 & Adj. R-squared & 0.385 & 0.043 \\
\hline Sum sq. resids & 0.044 & 0.010 & Sum sq. resids & 0.040 & 0.012 \\
\hline S.E. equation & 0.026 & 0.013 & S.E. equation & 0.025 & 0.014 \\
\hline F-statistic & 10.116 & 0.471 & F-statistic & 11.198 & 1.747 \\
\hline Mean dependent & 0.020 & 0.020 & Mean dependent & 0.004 & 0.004 \\
\hline S.D. dependent & 0.033 & 0.013 & S.D. dependent & 0.032 & 0.014 \\
\hline
\end{tabular}

Note: Bolded coefficients are significant at the $5 \%$ level. Source: Own calculations using data from SARB (2018) and Stats SA (2020).

sector. Of course, this holds only if the described earnings pattern remains stable. According to the findings, public-sector earnings will follow private-sector earnings, but not the other way around.

In the case of an imported inflationary shock (e.g. through rising oil prices) according to the estimated VECM, any response of private-sector wages will also affect public-sector wages, which would increase fiscal stress. In this situation, the dividend from credible monetary policy preventing an imported price shock to initiate a wage-price spiral is considerable.

Given the atheoretic nature of Granger-causality analysis and the VECM methodology, the paper does not make statements about the transmission process of wages between the private and public sector. This could be the topic of a follow-up study.

Supplementary Information The online version contains supplementary material available at https://doi. org/10.1007/s1 1293-020-09684-0. 
Acknowledgments The first author worked on this project during his visiting research fellowship at the Economic Research and Statistics Department of the South African Reserve Bank (SARB). Earlier research assistance by Siobhan Redford and Elmarie Nel is gratefully acknowledged. An earlier version of this paper was presented at an internal seminar and the constructive suggestions from participants are gratefully acknowledged. Robert Kunst and Martin Wagner provided helpful methodological advice. The views expressed in this paper are not necessarily shared by the current or former affiliations of the authors. Any remaining errors are the sole responsibility of the authors.

Funding Open access funding provided by TU Wien (TUW).

Open Access This article is licensed under a Creative Commons Attribution 4.0 International License, which permits use, sharing, adaptation, distribution and reproduction in any medium or format, as long as you give appropriate credit to the original author(s) and the source, provide a link to the Creative Commons licence, and indicate if changes were made. The images or other third party material in this article are included in the article's Creative Commons licence, unless indicated otherwise in a credit line to the material. If material is not included in the article's Creative Commons licence and your intended use is not permitted by statutory regulation or exceeds the permitted use, you will need to obtain permission directly from the copyright holder. To view a copy of this licence, visit http://creativecommons.org/licenses/by/4.0/.

\section{References}

Afonso, A., \& Gomes, P. (2014). Interactions between private and public sector wages. Journal of Macroeconomics, 39(PA), 97-112.

Agudelo, S.-A., \& Sala, H. (2016). Wage setting in the Colombian manufacturing industry. The Economics of Transition, 24(1), 99-134.

Ahrend, R., de Rosa, D., \& Tompson, W. (2007). Russian manufacturing and the threat of 'Dutch Disease': A comparison of competitiveness developments in Russian and Ukrainian industry. OECD Economics Department working papers, no. 540, Paris: OECD Publishing. https://www.oecd-ilibrary. org/docserver/322823013852.pdf?expires=1593429966\&id=id\&accname=guest\&checksum=A903A5 C0797C29CC9D19087DAC430949. Accessed 5 Jan 2020.

Alm, J., \& Embaye, A. (2010). Explaining the growth of government spending in South Africa. South African Journal of Economics, 78(2), 152-169.

Biesenbeek, C., \& Werff, S. (2019). Public-private wage differentials: Evidence from the Netherlands. De Economist, 167(1), 23-43 Springer.

Bosch, A. (2006). Determinants of public- and private-sector wages in South Africa, Labour Market Frontiers, South African Reserve Bank, 17-25. https://www.resbank.co.za/Lists/News\%20and\%20 Publications/Attachments/345/Determinants\%20of\%20public\%20and\%20private-sector\%20wages $\% 20$ in\%20SA.pdf.

Calmfors, L., \& Driffill, J. (1988). Bargaining structure, corporatism and macroeconomic performance. Economic Policy, 3(6), 13-61.

Calmfors, L., \& Seim, A.-L. (2013). Pattern bargaining and wage leadership in a small open economy. The Scandinavian Journal of Economics, 115(1), 109-140.

Coco, A., \& Viegi, N. (2019). The monetary policy of the South African Reserve Bank: Stance, communication and credibility. Working Papers 788, Economic Research Southern Africa. https://pdfs. semanticscholar.org/2d0b/9743935c52dd49c3d5b6d0f7ba5ec81e71ae.pdf. Accessed 5 Jan 2020.

Cooley, T. F., \& Leroy, S. F. (1985). Atheoretical macroeconometrics: A critique. Journal of Monetary Economics, 16(3), 283-308 Elsevier.

Coricelli, F., Cukierman, A., \& Dalmazzo, A. (2006). Monetary institutions, monopolistic competition, unionized labor markets and economic performance. The Scandinavian Journal of Economics, 108(1), $39-63$.

D’Adamo, G. (2014). Wage spillovers across sectors in Eastern Europe. Empirical Economics, 47(2), 523552.

Fearon, G. (2004). Public sector wage settlement and the threat of outsourcing. Atlantic Economic Journal, 32(3), 161-174.

Frisch, H. (1977). The Scandinavian model of inflation: A generalization and empirical evidence. Atlantic Economic Journal, 5(3), 1-14. 
Gwatidzo, T., \& Benhur, M. (2013). Mining sector wages in South Africa. Labour Market Intelligence Partnership (LMIP) working paper 12013. http://www.psetresearchrepository.dhet.gov. $\mathrm{za} /$ sites/default/files/documentfiles/01\%20HSRC\%20LMIP\%202013\%20WP1\%202013\%20Mining\%20 Sector\%20Wages\%20WEB_0.pdf. Accessed 5 Jan 2020.

Johansen, S. (1991). Estimation and hypothesis testing of cointegration vectors in gaussian vector autoregressive models. Econometrica, 59(6), 1551-1580.

Juselius, K. (2006). The cointegrated VAR model: Methodology and applications. Oxford: Oxford University Press.

Knell, M., \& Stiglbauer, A. (2012). Reference norms, staggered wages, and wage leadership: Theoretical implications and empirical evidence. International Economic Review, 53(2), 569-592.

Lamo, A., Pérez, J.-J., \& Schuknecht, L. (2012). Public or private sector wage leadership? An international perspective. The Scandinavian Journal of Economics, 114(1), 228-244.

Lindquist, M.-J., \& Vilhelmsson, R. (2006). Is the Swedish central government a wage leader? Applied Economics, 38(14), 1617-1625.

Marshall, R.-C., \& Merlo, A. (2004). Pattern bargaining. International Economic Review, 45(1), 239-255.

Mavromaras, K., Mahuteau, S., Mavromaras, K., Richardson, S., \& Zhu, R. (2017). Public-private sector wage differentials in Australia. The Economic Record, The Economic Society of Australia, 93(S1), 105121.

NDP. (2012). National Development Plan 2030 our future - make it work. National Planning Commission, South African Government, Pretoria. https://www.gov.za/sites/default/files/gcis_document/201409/ndp2030-our-future-make-it-workr.pdf. Accessed 5 Jan 2020.

NGP. (2011). The new growth path: Framework. Economic Development Department, South African Government, Pretoria. http://www.economic.gov.za/communications/publications/new-growth-pathseries. Accessed 5 Jan 2020.

Odhiambo, N. M. (2009). Savings and economic growth in South Africa: A multivariate causality test. Journal of Policy Modeling, 31(5), 708-718 Elsevier.

Pollan, W. (2004). Pattern bargaining and wage leadership in Austria. Austrian Economic Quarterly, 9(2), 88101.

Ramskogler, P. (2012). Is there a European wage leader? Wage spillovers in the European monetary union. Cambridge Journal of Economics, 36(4), 941-962.

South African Reserve Bank (SARB). (2018). Quarterly bulletin. Pretoria. https://www.resbank.co. za/Publications/Detail-Item-View/Pages/Publications.aspx?sarbweb=3b6aa07d-92ab-441f-b7bf-bb7dfb1 bedb4\&sarblist=21b5222e-7125-4e55-bb65-56fd3333371e\&sarbitem=8985. Accessed 5 Jan 2020.

Statistics South Africa (Stats SA). (2020). Consumer Price Index (CPI), Pretoria. http://www.statssa.gov. za/publications/P0141/P0141July2020.pdf. Accessed 5 Jan 2020.

Wittenberg, M., \& Kerr, A. (2019). Wage determination in South Africa: The case of the union wage premium since the end of apartheid. REDI3x3 Working paper 56, May 2019. https://www.redi3x3. org/sites/default/files/Wittenberg\%20\%26\%20Kerr\%202019\%20REDI3x3\%20Working\%20 Paper\%2056\%20The\%20union\%20wage\%20premium\%20in\%20SA.pdf. Accessed 5 Jan 2020.

Publisher's Note Springer Nature remains neutral with regard to jurisdictional claims in published maps and institutional affiliations. 